\title{
Barbaridades e violências
}

DoI

http://dx.doi.org/10.11606/ 2179-0892.ra.2017.141648

\section{Brigitte Bagnol}

University of the Witwatersrand | Johannesburg, África do Sul

$\boldsymbol{\nabla}$ bagnolbrigitte@gmail.com

RESUMO

A autora delineia a sua trajetória de convivência íntima com as violências e com as consequências infligidas na mente e no corpo de todas as pessoas que estão envolvidas nelas. Com exemplo de Moçambique, África do Sul e Ruanda e violências ligadas a guerra, a fome, ao HIV/AIDS e ao gênero ela articula, percorrendo fragmentos de suas experiências, as diferentes camadas e formas de violência que afligem os/as mais desemparados/as. A aproximação da violência física, da violência estrutural, da violência simbólica e das suas várias combinações destroem os seres humanas e, sobretudo, os/ as que têm de conviver com a multiplicidade das suas formas. A proposta é de encontrar formas de desenvolver uma nova ética de cidadania, de empatia e solidariedade que procura desarmar estas violências.
Palavras-chave

Violência, saúde planetária, fome, pobreza, gênero 
A verdade é (...) que um regime totalmente desumano como o nosso, longe de forjar seres capazes de construir uma sociedade humana, está modelando à sua imagem todos aqueles que lhe são submissos, tanto os oprimidos como os opressores (Weil, 1955).

\section{INTRODUÇÃO}

No ano de 1984, cheguei a Moçambique. 16 anos depois, em 2000, fui para a Africa do Sul. Em 2015, regressei a França. Minha trajetória foi mais orientada pela procura de respostas a perguntas de ordem política, que pelo resultado da história francesa no continente africano. De saída, a minha trajetória podia se resumir como de uma antropóloga francesa que atravessa a cortina de ferro para trabalhar num pais socialista lusófono em guerra. Esta travessia ia a contra corrente do que se entende geralmente por travessia da cortina de ferro. Não procurei sair dum país socialista para atingir um país capitalista, mas fui, como outros militantes de outros países da América Latina e da Europa, atrás de um projeto internationalista, que visava contribuir para inventar novas formas de relações sociais e econômicas internacionais.

Esta reflexão hoje me obriga a voltar o olhar sobre um processo que, por vários motivos, não gosto de abordar. O mais doloroso são os aspectos relacionados com as vivências e as sobre-vivências em tempo de guerra. Vivi, de 1984 a 1993, num Moçambique em guerra. O segundo motivo doloroso é que, tanto na África do Sul como em Moçambique, se vivem ainda hoje processos políticos e sociais tormentosos. Penso especificamente na guerra que re-eclodiu entre a FRELIMO e a RENAMO em 2014 após as eleições presidenciais em Moçambique, nas vagas de xenofobia desde 2008, no massacre de Marikana', em 2012 e no assassinato de mulheres lésbicas na Africa do Sul ${ }^{2}$ (Awondo et al. 2013). Um outro motivo doloroso está relacionado com a pobreza existente nestes dois países e que me desespera $\left(54 \%^{3}\right.$ da população vive na pobreza em Moçambique, e entre $53 \mathrm{e}$ $63 \%$ em África do $\mathrm{Sul}^{4}$ ). Assim, a primeira conclusão que tiro desta trajetória é a de uma convivência íntima com a violência e com as consequências infligidas na mente e no corpo de todas as pessoas que estão envolvidas nestas situações, as pessoas que cruzei e cruzo, as pessoas com que me relaciono e que são os meus amigos e minhas amigas. Esta violência faz parte das nossas vidas.

Talvez através desta reflexão, possa hoje começar a discutir a aproximação da violência física, da violência estrutural, da violência simbólica, de todas estas formas de violência que combinadas destroem os seres humanas e, sobretudo, os que têm de conviver com a multiplicidade das suas formas. O meu projeto é cruzar momentos, fragmentos desse momentos cristalizados em histórias,

1 Ver "Miners shot down", de Rehad Desai. Disponível em: https://www.youtube.com/ watch?v=8QMOm2WmZ4Y. Muholi, disponível em: https:// www.icp.org/perspective/ shifting-the-negative-anevening-with-zanele-muholi.

3 Disponível em: http:// noticias.sapo.mz/info/ artigo/1435956.html.

4 Disponível em: http:// theconversation.com/ how-current-measuresunderestimate-the-level-ofpoverty-in-south-africa-46704 
imagens, sensações, trabalhos, justapor o meu dia-dia, os anos, as décadas vividas, tendo algumas perguntas na cabeça. Como sair da violência? Que ética individual e coletiva desenvolver para acalmar esta violência? Como desenvolver a noção de solidariedade? Como mostrar que os/as mais pobres são pobres devido a um sistema que os/as oprime? Como ensinar o respeito pelo outro e pela diferença? Como acarinhar as diferenças? Como ensinar o respeito à diversidade das plantas, dos animais? Como fazer frente à monocultura, tanto na produção alimentar, como na produção intelectual? A reflexão neste artigo será necessariamente incompleta, mas tentará abordar um problema complexo e importante. Este assunto da violência vem sendo ratado de várias formas, por diferentes autores, no campo da filosofia (Walter, 1921; Arendt, 2010; Sontag, 1993; Sen, 1981, 2006; Mbembe, 2010, 2016) ou da antropologia (Misago et al., 2009; Hadland, 2008; Das, 2007; Nnaemeka, 2005, Farmer, 2004; Héritier, 1996; Bourdieu, 1993; El Saadawi, 1980; Cirard, 1972). A minha proposta é apresentar algumas das várias violências com as quais convivo e encontrar formas de desenvolver uma nova ética de cidadania, de empatia e solidariedade que procura as desarmar.

\section{O PONTO DE PARTIDA. GENEALOGIA DA NECESSIDADE DA PARTIDA, DA RUTURA}

A necessidade de se desconstruir e de se reconstruir, é algo que me vem acompanhando há muito. Necessidade de se reeducar, de se reformatar, de sair de si e de se impregnar de outras realidades e outras formas de pensar. Necessidade de ver e compreender a partir de uma organização trotskista, feminista, dos países não-alinhados, ver e entender a partir do Sul. Experimentar a partir de um grande número de pontos de vista. Testar outras perspectivas. O mais possível. Colocar-se na posição do outro. Aprender a viver fora da sociedade de consumo, fora do seu universo de referência. Sonhar em queimar o seu passaporte. Adquirir outras nacionalidades. Desejar viver 20 anos na Ásia, 20 anos na África, 20 anos na Europa e 20 anos na América Latina. Procurar entender posicionando-se fora do seu próprio contexto, fora da sua matriz cultural. Procurar sempre, porque nada é simples e nunca é possível ter a certeza que entendemos.

Tomar consciência do impacto da escravidão, do colonialismo, do regime do apartheid, do racismo e das suas consequências, entender também o ponto do visto dos colonos pobres instrumentalizados por uma política expansionista, uma ideologia fascista e racista, uma religião proselitista. Acompanhar os vitoriosos, mas entender também o ponto de vista dos "não-politicamente corretos", dos perdedores das guerras.

De onde vem esta necessidade de destruir e reconstruir, de ir procurar fora? Ela está presente no existencialismo, na concepção sartriana de que é possível 
construir-se e fazer de si o que se quer: "O importante não é aquilo que fazem de nós, mas o que nós mesmos fazemos do que os outros fizeram de nós" (Sartre,1952: 63). O ser humano forma a essência da sua vida com as suas próprias ações: O ser humano é condenado a ser livre, "porque uma vez jogado no mundo ele é responsável por cada coisa que ele faz" (Sartre, 1978:9).

André Gide indica a possibilidade de outros caminhos: em Les Nourritures terrestres (1927), ensina com insolência o fervor, o prazer carnal, fé nas manhãs e nas partidas, no desenraizamento - "Famílias odeio-vos! Casas fechadas, portas fechadas, possessão ciumenta da felicidade" (Gide, 1927: 77). Mas ensina também a fome e a privação. Para estar disponível, não há entraves nem mesmo os de um discípulo: "Nathanaël, agora joga fora o meu livro, liberta-te" (Gide, 1927: 207), porque é responsabilidade individual construir uma moralidade pessoal. "É porque és diferente de mim que te amo; amo em ti somente aquilo que difere de mim. Educar! Quem posso educar senão eu mesmo? Nathanaël, posso te dizer? Eu me eduquei interminavelmente. E continuo. Somente me estimo naquilo que poderei fazer" (Gide, 1927: 207). Estas exortações soavam em harmonia com Bob Marley (1980) "Emancipate yourself from mental slavery, none but ourselves can free our minds". Acreditava-se numa possibilidade de mudança radical.

Em 1972, o Clube de Roma atraiu a atenção pública com o relatório The Limits to Crowth (Os limites do crescimento), que examinava os cinco fatores básicos que determinam e limitam o crescimento neste planeta (aumento da população, produção agrícola, depressão de recursos não-renováveis, produção industrial e poluição). No liceu em Avignon, em 1973, eu estudava "L'Utopie ou la mort" (A utopia ou a morte) publicado naquele ano por René Dumont, que analisava o limite da Revolução Verde promovida com "sementes milagrosas", monocultura e aumento de uso de pesticidas e fertilizantes. Ele denunciou as consequências negativas do crescimento populacional e econômico descontrolado e os padrões de consumo em grandes sociedades industriais. Tornando-se um grande oponente do liberalismo, ele não deixou de lutar por um mundo mais justo e mais ecológico. Dumont advogou uma agricultura e uso diferentes de recursos e foi um dos primeiros promotores de um desenvolvimento sustentável (Dufumier, 2007). Dumont queria moldar um ser humano novo que fosse capaz de aceitar os constrangimentos relacionados com o crescimento zero do seu consumo. A noção de utopia, presente no título do livro, está ligada a este novo ser humano numa sociedade ecológica, que controla a sua natalidade, sua produção industrial e agrícola de forma racional para não esgotar os recursos naturais e não contribuir para o aquecimento do planeta.

As leituras marxistas, o materialismo histórico acompanharam a minha partida. Impregnei-me da compreensão das formas de exploração expressas em OCapital: 
A descoberta de regiões a uríferas e argentíferas, a redução dos indígenas em escravos, seu enterramento nas minas ou sua exterminação, o início de conquistas e pilhagens nas Índias orientais, a transformação da África num tipo de reserva comercial para a caça das peles negras, eis os procedimentos idílicos de acumulação primitiva que caracterizam a era capitalista na sua aurora (Cênese do capitalista industrial, Marx, 1973: 193).

Estava consciente que o capitalismo impunha o consumo ilimitado de bens para o aumento do seu lucro. Sair da sua engrenagem era a única alternativa e o internacionalismo uma opção.

\section{A DESILUSÃo, O DESENCANTO}

No final dos anos 70, quando era uma jovem militante trotskista na França, entendi rapidamente que a nossa organização (Organização Comunista Internacionalista-OCl) não estava dando atenção, de modo algum, às questões das mulheres. A organização política era extremamente patriarcal e machista. A maioria dos membros e dos dirigentes eram homens, a história que se relatava e as análises que se fazia das situações politicas no mundo só diziam respeito aos problemas dos homens. As figuras femininas, com exceção de Rosa Luxembourg, eram ausentes. A posição das mulheres na sociedade e na história eram aspectos inexistentes. Como mulheres, para discutir e defender o aborto legal livre, tivemos de nos juntar a outras organizações porque dentro da $\mathrm{OCl}$ estes assuntos não eram prioritários. Eu já estava trabalhando em torno de questões de violência contra as mulheres, especificamente sobre as mutilações sexuais femininas. A tensão entre estar envolvida numa organização unicamente de mulheres ou numa organização política abordando questões de opressão de uma forma mais ampla, foi um grande dilema. À questão do feminismo se adicionava a questão da burocratização da organização e do centralismo democrático. Fui afastada da organização.

Quando cheguei em Moçambique, em 1984, a política revolucionária era clara. A Frente de Libertação Moçambicana (FRELIMO), depois de 10 anos de guerra contra o domínio colonial, proclamou a independência de Moçambique em junho de 1975. A FRELIMO adotou uma abordagem socialista e marxista-leninista com a nacionalização da saúde, da educação, das habitações, com a modernização da produção agrícola, as empresas estatais e a economia centralmente planificada pelo Estado5. A FRELIMO rejeitou a sociedade "tradicional". A FRELIMO, com a Organização da Mulher Moçambicana (OMM) e as outras organizações de

5 Ver Joseph Hanlon (1984 e 1997) massa, lutou contra ideias consideradas retrógradas, organizando campanhas políticas contra os médicos tradicionais, os ritos de iniciação, o lobolo (casamento 
tradicional), a poligamia, as relações extraconjugais e os casamentos precoces. Semelhante aos eventos ocorridos durante a Revolução Cultural da China, foram realizadas campanhas para erradicar os vestígios de qualquer forma de exploração e tradição. O discurso de abertura por Samora Machel a Primeira Conferência da Organização da Mulher Moçambicana realizada na Tanzânia, em 1973, ainda durante a guerra de libertação, delineava a posição do movimento sobre a libertação das mulheres: "A libertação das mulheres é uma necessidade fundamental para a Revolução, uma garantia de sua continuidade e uma condição prévia para a sua vitória" (Machel,1974: 2). A libertação das mulheres e dos homens eram vistas como indivisíveis nos primeiros anos após a independência, mas, lentamente, as mulheres começaram a se sentir marginalizadas pelo processo. Novas estratégias deviam ser colocadas em prática na medida em que a libertação do colonialismo e o esforço para construir uma sociedade comunista não responderam à luta das mulheres pela igualdade.

Por outro lado, rapidamente, desde da minha chegada, o desmoronamento deste projeto socialista foi claro com o seu centralismo, o culto da personalidade, os campos de reeducação, a repressão das várias formas de expressão cultural, o aldeamento forçado etc. Para mim, a tensão entre a agenda feminista e uma agenda política ampla que estava em discussão novamente tornou óbvia a impossibilidade de se conceber e se realizar as duas agendas.

O que apareceu, porém, foi que, se não se contribuía para construir o socialismo, se contribuía para acabar com o apartheid. O apartheid representava o regime político mais execrável. Vencer a guerra contra a RENAMO, que era apoiada pelo regime do apartheid e pelos serviços secretos rodesianos, era uma forma de enfraquecer o regime do apartheid e os seus aliados na região. No fim dos anos 80, Moçambique estava exangue, a economia, essencialmente agrícola, destruída, cerca de um terço da população refugiada nos países vizinhos. $O$ pais dependia em $70 \%$ do seu PNB da ajuda internacional. As ajudas anteriormente vindas da URSS escassearam devido aos problemas econômicos e políticos que lá reinavam. Moçambique teve que procurar então a ajuda de países do outro bloco ideológico e aceitar as mudanças e as reformas exigidas pelas instituições de Bretton Woods. Com a queda do muro de Berlim em 1989, caiu a cortina de ferro e tomou fim a Cuerra Fria. Com a queda do muro de Berlim, caía o sonho de ver nos países recém-libertados do colonialismo novas formas de produção, de democracia, de relação entre os seres humanos e com a natureza. Com o fim dos confrontos ideológicos entre os dois blocos, observou-se uma rápida expansão da democracia liberal e do capitalismo selvagem. O fim da guerra em Moçambique, em 1992, precedeu em pouco o fim do apartheid, em 1994. Mais de 100 mil pessoas tinham perdido a vida em Moçambique.

Comecei a trabalhar sobre o lobolo e as formas de violência com ele relacionadas 
(Bagnol, 2006, 2008): violência social e violência religiosa. O lobolo é, nesta região, o termo usado para se referir ao casamento costumeiro, bem como os presentes que a parentela do noivo oferece à parentela da noiva. Este estudo mostra que os descendentes podem ser vítimas de agressão por parte dos espíritos da família de uma antepassada cujo lobolo não foi dado. Assim, a maioria dos problemas sociais e das doenças tem uma origem relacional e, como forma de prevenção, as pessoas devem seguir normas e comportamentos sociais contextualizados. Os diagnósticos geralmente identificam espíritos ou feiticeiros/as que originaram o problema (Bagnol, 2017). Inscrito nas diferentes práticas religiosas que os indivíduos realizam, o lobolo participa da construção do poder simbólico (Bourdieu, 1989).

Mudei-me de Moçambique para a África do Sul em 2000. Nestes anos, acreditava-se que a África do Sul, repentinamente, tinha se tornado uma nação arco-íris com pessoas de diversas origens e com direitos iguais. Aqueles que até então viviam separados estavam "de boa ou má vontade, bem-sucedidos ou não, envolvidos em um dos mais profundos ajustamentos psicológicos coletivos do mundo contemporâneo" (2001a: xxi). "A abolição do regime do apartheid possibilitou o acesso a espaços, independente de origem 'racial', e a contestação das fronteiras consagradas pelos conceitos reificados das identidades 'raciais"' (Blaser, Bagnol, Matebeni, Simon e Manuel, 2010:117). E era nestes "profundos ajustamentos psicológicos coletivos do mundo contemporâneo" que eu queria participar.

O entendimento de que a convivência de "negros" e "brancos" está baseada na injustiça, continua presente. Existe em muitos espaços a compreensão de que os "brancos" se beneficiaram do apartheid e continuam a fazê-lo sem arrependimento.

Apesar de essa visão ter como base um passado que separa os "negros" e os "brancos", as mudanças nas condições sociais e econômicas criam novas identidades que estão incorporadas ou emaranhadas, como sugere Sarah Nuttall (2004), nas maneiras de ser européias ou "brancas" (Blaser, Bagnol, Matebeni, Simone Manuel , 2010:121-122).

A consciência de que resta ainda muito para fazer para permitir às pessoas previamente discriminadas aceder à estima de si, à educação, a um trabalho, a um serviço de saúde de qualidade é muito generalizada. Este descontentamento é especificamente expresso nos recentes movimentos estudantis "Rhodes must fall" "Fees must fall" " "Decolonising the university". O movimento "Rhodes must fall" iniciou-se em março de 2015 com uma campanha para remover a estátua de Cecil Rhodes da Universidade de Cape Town. Rhodes (1853-1902) era um businessman inglês, um magnata da indústria mineira sul-africana, que fundou o Southern African Territory of Rhodesia (Territórios da África Austral da Rodésia, agora Zimbabwe e Zâmbia) ao qual ele deu seu próprio nome. $O$ 
movimento "Rhodes must fall", se espalhou pelas universidades na África do Sul, na Inglaterra e nos Estados Unidos, exigindo uma melhor representação da cultura "não branca" no currículo da universidade. Este movimento, como as iniciativas de discriminação positiva em relação às pessoas previamente discriminadas implementadas na África do Sul, bem como no Brasil, indicam uma dinâmica positiva para uma mudança de paradigmas, de formas e conteúdo de ensino e de intervenções práticas para procurar amenizar as desigualdades de raça.

Estas reivindicações, estas medidas, não combinam uma abordagem de gênero e não contribuem assim para amenizar as desigualdades de gênero também. Sugiro perceber que todas as discriminações são uma discriminação e que qualquer ataque a dignidade humana é um ataque inaceitável, ao invés de continuamente fragmentar as abordagens. Fragmentar os indivíduos em identidades múltiplas e separar as várias esferas de luta em vários movimentos é contraproducente. $\mathrm{O}$ que aconteceu aos movimentos progressistas para raramente integrar os aspectos de gênero nas suas análises e suas agendas?

\section{A IMIGRANTE: O CASO DE JOHANNESBURGO}

Na terça-feira, 13 de maio de 2008, às oito da manhã, o meu celular toca. É a Thandiwe, a jovem zimbabwana que trabalha algumas horas por semana em casa.

Eles querem matar-nos. Tenho medo de sair. Estamos na casa mortuária ou no hospital. Eu não dormi ontem à noite, estávamos correndo pelas ruas. Dormimos na rua porque se eles nos a panham, eles vão nos bater e nos matar e tomar as nossas coisas. Eles tomam tudo, a TV, o vídeo, a geladeira, os cobertores, as roupas, o celular, o dinheiro. Se dormimos lá fora, quando eles vierem, podemos correr atrás da árvore. Consegue ouvi-los? Consegue ouvi-los? Consegui ouvi-los no telefone? Eles estão vindo... as pessoas estão correndo na rua. Eu tenho medo. Oh! Eu tenho medo. Eu irei mais tarde. Tenho medo de ir para a rua e então eles se me virem, eles vão começar a falar em zulu. Eles cumprimentam você em zulu e se você não souber como responder, eles te batem. Eu conheço o Ndebele. Não conheço a língua deles... É por causa de Tsvangirai, porque ele disse que perdeu as eleições porque a maioria das pessoas está em África do Sul e nós não votamos. Agora ele enviou 100 ônibus para que possamos votar. Cada um de nós recebeu um documento com explicação para pegar o ônibus e ir votar. Eles estão nos matando por causa dele (Tsvangirai). Eles dizem: "vão para Zim (Zimbabwe) para votar". Eles dizem que estamos tirando-Ihes o trabalho e estamos cometendo crimes. Eles roubaram todo o tomate, todas as coisas que as pessoas estão vendendo na rua. No domingo mataram 12 . Ontem mataram duas pessoas. 
Thandiwe ofega, ela repete várias vezes as mesmas informações, sente-se caçada, sente-se perdida.

Esta violência me sufoca e me revolta. Recolho elementos com várias texturas em lugares diferentes, recortes, vídeo, fotografias, notas, pesquisas, e sempre a mesma pergunta: o que fazer com isso? O que se faz com tanta violência acumulada? Como podemos sair dela? Como posso sair dela? As perguntas continuam sendo as mesmas.

No dia 29 de março de 2008, no Zimbabwe, realizou-se o primeiro turno das eleições presidenciais que opunham Robert Mugabe (Zimbabwe African National Union - Patriotic Front, ZANU-PF) e Morgan Tsvangarai (Movement for Democratic Change, MDC). As eleições desenrolaram-se num contexto de grande violência política e de crise econômica e social.

Estas eleições aconteciam num país que tinha conquistado a sua independência em 1980 depois de 15 anos de luta armada contra um regime de uma minoria branca que tinha unilateralmente decidido a independência da antiga Rodésia (atualmente Zimbabwe) da Inglaterra em 1965. O presidente Mugabe lidera o país desde 1980. Foi primeiro ministro e desde 1986 e é presidente. Apesar da existência de um programa de reforma agrária desde a década de 1980, a população branca, que representava cerca de 0,6\% da população, detinha $70 \%$ da terra agrícola mais fértil do país e, em 2000, o governo prosseguiu com o seu programa de confiscação e redistribuição de terra. Esta decisão, junto com uma série de períodos de seca, com a degradação dos apoios financeiros externos, levaram a queda da produção agrícola. O Presidente Mugabe enfrentou uma ampla gama de sanções internacionais. Em 2002, o Zimbabwe foi suspenso da Commonwealth.

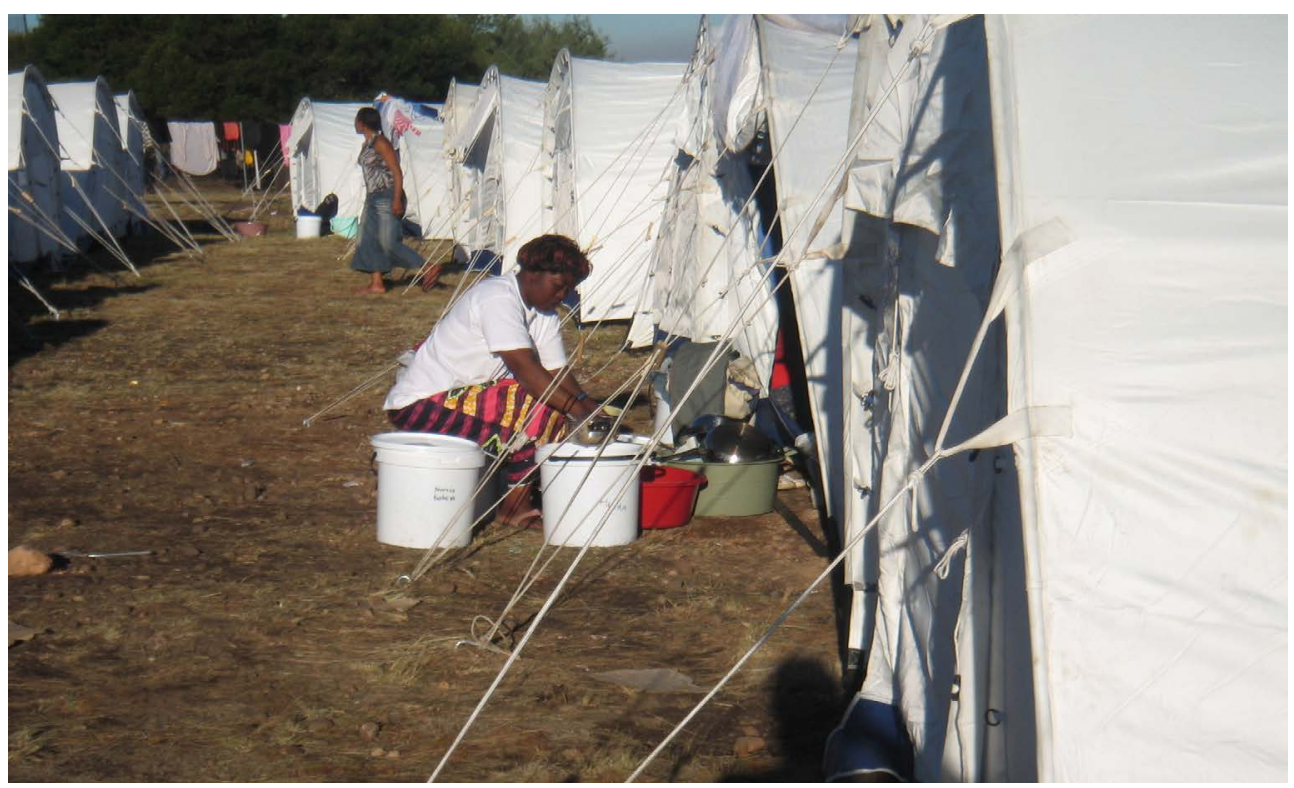

\section{Figura 1}

Um campo de pessoas refugiadas em Johannesburgo devido à violência xenofóbica, junho de 2008. Foto de Brigitte Bagnol. 
No primeiro turno das eleições do 29 de março de 2008, a ZANU-PF obteve 97 cadeiras com $43.2 \%$ e votos e o MDC 99 cadeiras, com $47.9 \%$ dos votos ${ }^{6}$. Com a divulgação dos resultados, a violência escalou consideravelmente com ataques a instalações do MDC, assassinato de líderes políticos da oposição, violação coletiva de mulheres apoiantes do MDC, levando muitas pessoas a imigrar para a África do Sul. O clima era insustentável. Em 2008 a inflação era a mais alta do mundo com $2200000 \%$ em julho de 2008 . O desemprego atingia $80 \%$ nas zonas urbanas (Castelo Branco, 2008), como resultado da política de redistribuição de terras. O colapso dos setores agrícolas, de extração mineira, do turismo tornaram a situação econômica insuportável. A situação na saúde também era dramática, com cerca de $26 \%$ da população adulta com HIV/AIDS em $1999^{7}$ e o sistema de saúde a desmoronar, caracterizado pela ausência de pessoal e de medicamentos. Em consequência deste contexto, 3 dos 13 milhões de habitantes saíram do pais ${ }^{8}$. No início de maio, o MDC declarava 30 líderes e apoiantes assassinados, centenas de outros torturados e presos e estimava-se que 40 mil pessoas estavam deslocadas desde o primeiro turno das eleições ${ }^{9}$. A conjuntura era tal que Tsvangarai, em 22 de junho de 2008 , desistiu de concorrer para o segundo turno, considerando que, no contexto em que se vivia, a eleição poderia não ser justa e não queria ariscar a vida dos seus seguidores ${ }^{10}$.

Thandiwe tinha 21 anos de idade e viera do Zimbabwe havia alguns meses neste contexto de crise econômica e financeira para se juntar aos seus pais e ao marido que viviam em Alexandra, um subúrbio de Johannesburgo. Um número cada vez maior de pessoas, incluindo mulheres e crianças, estão em movimento tanto internamente como internacionalmente em busca de diferentes soluções para a sua segurança ou buscando melhores padrões de vida. Pobreza, problemas sociais, instabilidade econômica ou política, fonte instável de renda, falta de recursos, contribuem para a vulnerabilidade das pessoas. Para eles, a migração é uma estratégia para diminuir sua vulnerabilidade em diferentes esferas da sua vida. Como Tandiwe, milhares de homens, de mulheres, de crianças estiveram nas estradas muitas vezes durante vários meses antes de encontrar um espaço para parar. Em muitos casos, o espaço encontrado não é apropriado nem completamente seguro e viverão uma vida inteira de discriminação. Discriminações de classe, culturais, religiosas ou somente ligadas à sua nacionalidade, à sua diferente origem. As ondas de violência xenófobas em Johannesburgo são um exemplo da dificuldade de integrar pessoas de origem diferentes. As barreiras à entrada de refugiados/ as e imigrantes na Europa são expressões dos mesmos processos de fechamento em si mesmo, isolamento, afastamento dos outros, institucionalização da violência. Pergunto-me, como Sen (2006), como é possível que a noção de identidade, com características limitadas, seja tão valorizada em detrimento
6 Disponível em: http://www.asemana.publ. cv/?Mandela-critica-violenciapolitica-no-Zimbabwe

7 Disponível em: http://pubs.sciepub.com/ ajcmr/1/1/5/index.html

8 Disponível em: http://populationsdumonde. com/la-population-duzimbabwe-atteint-13millions-dhabitants

9 Disponível em: http://www.smh.com.au/ world/40000-displaced-inzimbabwe-since-pollingunion-20080508-2c9d.html

10 Disponível em: https://jpn.up.pt/2008/06/23/ zimbabue-tsvangirai-desisteda-candidatura-a-segundavolta-das-presidenciais/ 
da multiplicidade de características que nos une e que partilhamos. Como é possível, como questiona Mbembe (2017), que fronteiras erigidas artificialmente possam servir como barreiras para manter os outros à distância? Como não reconhecer que pertencemos todos à mesma história e que esta história ou estas histórias se comunicam, estão imbricadas as umas nas outras de mil e umas formas? Por exemplo, quando circulo na cidade de Bordeaux, na França, é a história da escravidão e são as riquezas roubadas no Haiti (Farmer, 2004) e outros países que cruzo. As ruas ainda têm o nome dos negreiros que cometeram crimes contra a humanidade.

Se a globalização deu a sensação de uma unificação tecnoeconômica do globo com o uso da internet, o telefone celular, o aumento das transações financeiras e comerciais mundiais, a rapidez e aumento do movimento das pessoas e mercadorias, observa-se do outro lado um maior encolhimento sobre si mesmo, seja este ideológico, cultural ou religioso.

\section{GÊNERO E HIV/AIDS}

Uma outra violência com a qual lido diariamente é a violência exercida contra a metade da humanidade. Como explicar por que as mulheres no mundo são mais pobres e mais vulneráveis que os homens? Por que ganham $24 \%$ menos que eles (UN Women, 2015:79)? Por que trabalham nos setores mais mal pagos da economia do mundo, realizam cerca de duas e meia vezes mais trabalhos de cuidados e trabalhos domésticos não-pagos que os homens, trabalhando mais horas por dia do que estes (UN Women, 2015)? Por que, além de serem sujeitas a esta violência econômica e social, estão ainda sujeitas a violência física e psicológica nas relações humanas, sobretudo nas relações familiares? As mulheres tendem a ter menos direitos que os outros seres humanos pelo único fato de terem nascido mulheres, são discriminadas desde o berço e educadas a ser cidadãs de segundo nível, com menos acesso a todos os recursos e são vítimas de mais violência que os seus irmãos, maridos, companheiros, pais, tios, avós porque às violências contra os seres humanos no meio social e cultural onde elas vivem, adicionam-se todas as formas de violência especificas contra as mulheres. As discriminações de gênero banalizam a violência. A violência está presente na maioria dos lares porque, nas condições atuais, as mulheres, por mais que seus parceiros as respeitem, não são tratadas na sociedade como seres com todos os direitos.

Esta violência especifica contra as mulheres pode ser observada em todas as esferas da vida. Se olhamos para as áreas da economia, da agricultura, da educação, da saúde e para as esferas doméstica, pública e política, poderemos observar as várias formas de violência silenciosa, institucionalizada, que sempre mantêm as mulheres numa situação de subalternidade. Barreiras limitando o 
progresso das mulheres e impedindo a realização da igualdade de gênero estão, em parte, ligadas à incapacidade de promover a mudança de mentalidade e de atitudes, bem como à dificuldade de desmantelar as estruturas tradicionais e institucionais que impedem a promoção da igualdade de direitos das mulheres. Precisa-se encontrar formas de desmantelar as estruturas promovendo e institucionalizando a violência.

Irei tomar um exemplo na área da saúde. A África Austral enfrenta a epidemia de HIV/AIDS há já três décadas e registra ainda as prevalências mais altas ao nível internacional. Depois de anos e anos de trabalho de sensibilização por parte das organizações em prol da igualdade de gênero e de organizações feministas, conseguiu-se finalmente que fossem recolhidos dados desagregados por gênero e que fosse reconhecida a face feminina da epidemia. Dados recentes indicam que $13,2 \%$ das pessoas entre 15 e 49 anos vivem com HIV em Moçambique, incluindo 15,4\% de mulheres e meninas e 10,1\% dos homens e meninos (IMASIDA, 2015). Dois terços das novas infecções estão em meninas. As mulheres são desproporcionalmente afetadas, especialmente na faixa etária de 15 a 24 anos, uma vez que são 3 vezes mais propensas a serem infectadas com o HIV quando comparadas com homens da mesma idade. Embora a prevalência nessa faixa seja de 3,2\% para os homens, atinge 9,8\% nas mulheres. Registram-se também diferenças de acordo com a residência, o nível de educação e o nível de riqueza.

Para explicar esta situação existem fatores biológicos que predispõem à infecção por HIV e fatores econômicos, culturais, religiosos, legais e políticos que influenciam a possibilidade de as meninas e as mulheres exercerem seus direitos à integridade corporal, autonomia pessoal, igualdade e diversidade (Corrêa e Petchesky, 1996).

De uma forma geral, as mulheres, suportam as maiores consequências do ato sexual, que incluem a gravidez indesejada, as infecções de transmissão sexuais, como o HIV, e muitas vezes estão ausentes as condições que permitiriam o exercício dos seus direitos. As mulheres têm menor acesso à informação, educação, trabalho, terra, etc. Por isso, as raparigas e as mulheres se encontram numa situação de menor poder econômico e social. A iniquidade no acesso aos recursos por parte das mulheres implica iniquidade de poder, menos controle sobre a sua sexualidade e sua reprodução e, consequentemente, maior vulnerabilidade ao HIV.

As raparigas e as mulheres são quem mais cuidam dos doentes, sem ter preparação específica para tal. Adicionalmente, elas carregam a maior parte do peso emocional de cuidar dos doentes. As raparigas são muitas vezes retiradas da escola para cuidar de um familiar enfermo. Raparigas e mulheres carregam também a maior parte do peso econômico desta situação, sacrificando os seus estudos, suas carreiras profissionais ou as suas atividades de rendimento, porque a sociedade 
considera que é sua responsabilidade, como mulher, cuidar dos doentes.

A violência é um obstáculo para o desenvolvimento total das potencialidades da rapariga e da mulher e limita o seu controle sobre a sua própria saúde sexual e reprodutiva, colocando-as em situação de risco. O medo de desencadear uma reação violenta por parte do seu parceiro pode impedir que a mulher insista sobre o uso do preservativo ou se recuse a ter relação com um parceiro que sabe que tem, simultaneamente, outras parceiras. A violência contra as raparigas no seio familiar desde a mais tenra idade, perpetrada pelos seus próprios progenitores, familiares ou ainda por pessoas próximas da família, é frequente. Na escola, a violência continua na relação com colegas e professores, contribuindo para a destruição da sua autoestima, o aparecimento de insegurança e a perda de referências, pois os seus familiares e vizinhos, que teriam por obrigação protegê-las, são muitas vezes os seus agressores.

A relação entre o HIV e a pobreza é complexa (Mazzeo, Rodlach e Breton, 2011). Em muitos países, é na camada mais rica que a prevalência é maior. As pessoas das camadas mais pobres da sociedade geralmente morrem mais rapidamente devido à combinação com outras doenças, à desnutrição e à falta de acesso aos cuidados de saúde adequados. A morbilidade por outras doenças e por malnutrição aumentam a suscetibilidade biológica ao HIV e aceleram a progressão do HIV para a AIDS. As pessoas das camadas que têm mais acesso aos cuidados de saúde de qualidade têm mais possibilidade de viver muito tempo com a doença. Para aqueles que são pobres, o HIV os torna mais pobres. Para as mulheres, que representam a maior proporção dos pobres da sociedade, o HIV as torna ainda mais pobres.

\section{O CASO DE RUANDA}

Em julho de 2017, passei alguns dias nas aldeias em volta do Parque Nacional do Akagera, em Ruanda, com um grupo de estudantes universitários nacionais formados em diferentes áreas: saúde humana, saúde animal, ecologia, farmácia. Procuramos entender as interações entre as várias espécies, no âmbito de um curso intitulado Uma Saúde ou Saúde do Planeta.

Olhamos a paisagem de colinas. Numa perspectiva de 180 graus que se estendia à nossa frente, observamos e tentamos contar as árvores. Havia somente bananeiras, eucaliptos e pouquíssimas espécies indígenas. A diversidade das culturas comerciais e alimentares é muito limitada. Os campos perto do rio, no vale, eram ocupados essencialmente por arroz e poucas outras variedades alimentares. A dieta alimentar era pouco diversificada. Em Ruanda, as áreas protegidas perderam $50 \%$ da sua superfície nos últimos 40 anos e $90 \%$ das condições climáticas naturais desaparecerem, com uma perda massiva da biodiversidade 
(Twagiramungu, 2006). Observamos e conversamos com os rapazes em férias escolares que passavam a manhã na água, pescando. As raparigas iam buscar água. Por volta das 13 horas, manadas de bois apareciam para beber. Enquanto muitos homens trabalhavam nas minas de tungstênio, as mulheres zelavam pelas atividades domésticas e agrícolas.

O país, um dos mais densamente povoados de África e um dos mais pobres do mundo, procura se curar e cicatrizar do drama do genocídio de 1994, no qual morreram entre 500 mil e um milhão de pessoas, numa população de 7,6 milhões. Dois milhões fugiram do pais. Fatores históricos de ordem política, econômica, social contribuíram para o genocídio. O país estava atravessando uma fase de grave crise econômica ligada à queda do preço do café em 1989, perda da produção agrícola (devida à concentração das terras entre os mais ricos e a redução das terras cultivadas para o consumo alimentar) e a medidas econômicas implementadas pelo Fundo Monetário Internacional. As políticas coloniais, fomentando conflitos entre grupos linguísticos hutu e tutsi, a Guerra Fria, com o uso do país pelos países ocidentais para fazer face às independências regionais, também atuaram como fatores de base que contribuíram para a exacerbação da violência.

\section{Imagem 3}

Os instrumentos de cozinhas secam e no fundo o galinheiro. Zâmbia, 2015, Bunda Bunda, Distrito de Rufunsa.

Foto de Brigitte Bagnol.

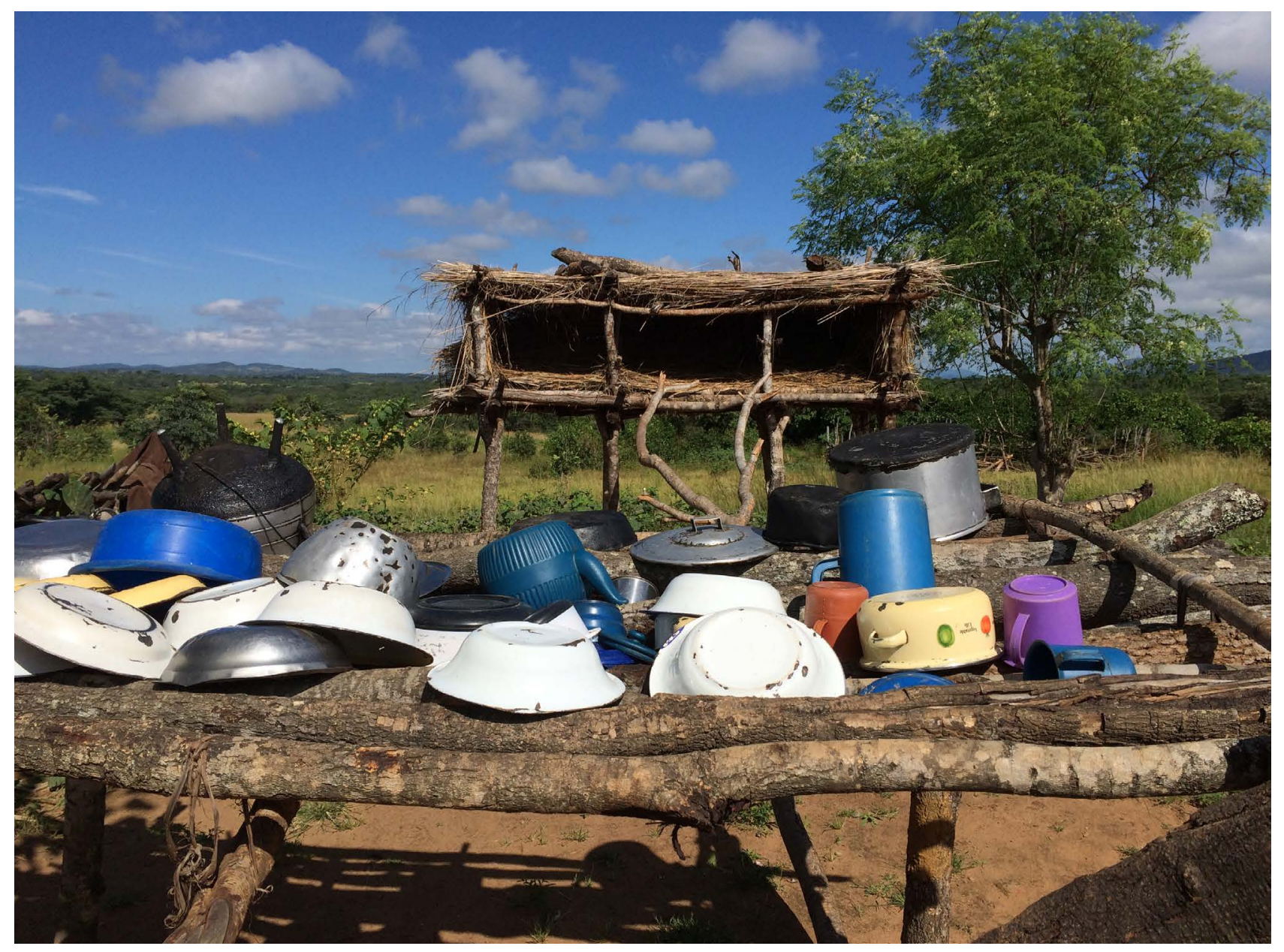


Sentada com os estudantes, eu procurava ler a paisagem, entender como estes fatores, estas violências acumuladas de gerações em gerações marcaram não somente as pessoas e as relações sociais, mas a natureza. A tensão e o medo ainda se faziam presentes nos rostos e nas conversas com os/as alunos/as e colegas. As respirações estavam suspensas, estávamos num intervalo, num meio tempo. Em qualquer momento, a violência poderia voltar. Esta violência está presente em todos os lados onde olhamos.

É esta paisagem humana e ecológica que cruzo em muitos lugares no Chade, Timor Leste, Moçambique, África do Sul. A doença do planeta, num mundo globalizado e interconectado, onde não somente os seres humanos, mas também as plantas, os animais e o meio ambiente estão em interação, é o resultado do capitalismo, do colonialismo, da escravidão, das pilhagens, das violências, das guerras, da procura do lucro, das ambições individuais e coletivas e dos medos. Estas pilhagens contínuas e ininterruptas que, ao longo de séculos, vêm contribuindo para o consumo excessivo pelos mais ricos, levaram ao desaparecimento de várias espécies. A pilhagem de recursos minerais e naturais condena a cada dia milhões de pessoas a viver na pobreza, na violência, na fome, a migrar num movimento incessante em busca de um pouco de alívio.

Olhando para as colinas em minha frente, vejo a minha história, a história da barbárie, esta história que marca os seres humanos e o planeta. Patrick Chamoiseau (2017:67), no seu último livro Frères migrants escreve: "Cette barbarie qui surdétermine l'économie, les techniques et les sciences fait du monde un lieu plus que jamais indissociable par la seule densité des misères qu'elle essaime ${ }^{11}$." De fato, aquele que não reconhece em volta de si a sua própria história, que não vê na miséria e no sofrimento do outro a marca da barbárie não poderá nunca compreender o que está acontecendo no mundo de hoje.

\section{FOME}

Este cenário de degradação ambiental, degradação social e econômica é muito frequente e aumentou com a crise econômica de 2008. O aumento descontrolado da população, resultante em grande parte de um limitado acesso à educação e um limitado empoderamento feminino, levou a população do planeta a atingir 7 bilhões em 2011. As projeções preveem que a população irá atingir 9,7 bilhões no meio do século e 11,2 bilhões no final do século (United Nations, 2015). Considerando que atualmente se estima que cerca de 795 milhões de pessoas, ou uma em cada nove, sofram de desnutrição crônica, pode-se entender a complexidade da situação (FAO, 2015). Quase todas as pessoas com fome, 780 milhões, vivem em países em desenvolvimento, representando $12,9 \%$, ou uma em cada oito pessoas da população desses países (FAO, 2015). Como alimentar a população
11 "Essa barbaridade que sobredetermina a economia, as técnicas e as ciências torna o mundo um lugar mais do que indissociável pela densidade das misérias que ele derrama". 


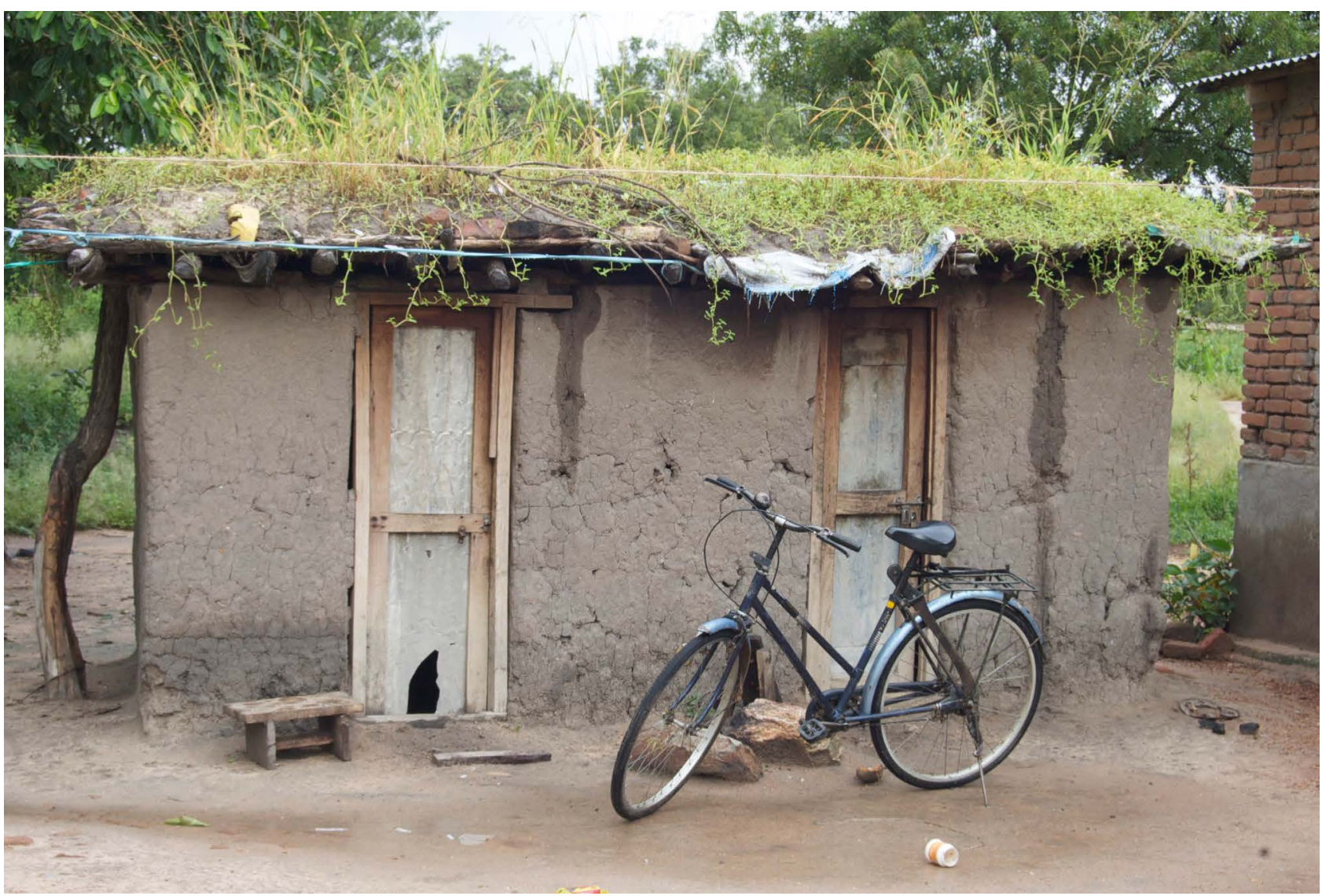

crescente do planeta é o dilema sobre o qual muitos cientistas estão trabalhando. Estimativas apontam para a necessidade da produção de alimentos aumentar cerca de 70\% em 2050 e dobrar ou triplicar em 2100 (Crist, Mora e Engelman, 2017). No entanto, como aumentar a produção alimentar quando se considera que o sistema de produção alimentar planetária, sobretudo a produção animal, contribui grandemente para as mudanças climáticas (Ripple et al., no prelo).

Em 1984, quando cheguei a Moçambique, considerava-se que o desenvolvimento agrícola só poderia ser realizado caso se abandonasse o sistema de produção "tradicional" e fosse adotado o sistema "moderno". O sistema "tradicional" consiste na seleção das melhores sementes de um ano para o outro, da consorciação das leguminosas com os cereais. "Moderno" significava mecanizado, monocultura e o uso de sementes melhoradas com fertilizantes e pesticidas. $\mathrm{O}$ aumento do rendimento era visto como um resultado milagroso que implicaria automaticamente uma melhoria do estatuto econômico e da saúde da população. O risco, o custo e a dependência envolvida, não eram discutidos (Cebru, 2015). Obrigava-se os camponeses a plantar em linha e a plantar somente uma cultura no seu campo. Contudo, os sistemas agrícolas não podem ser vistos como um sistema técnico e econômico realizado na fazenda sem se tomarem em consideração as razões socioeconômicas pelas quais os agricultores estão fazendo o que estão fazendo, da maneira que estão fazendo. Vários

\section{Figura 3}

Uma casa em Sanza District, Tanzânia, 2014. Foto de Brigitte Bagnol. 
estudos destacam as diferentes vantagens (Gebru, 2015) da consorciação para fertilização (Zhang e Li, 2003), rendimento, umidade e gerenciamento de ervas daninhas (Matt e Dyck, 1993). A consorciação é vivamente encorajada agora pelos agrônomos que trabalham no sentido de uma agricultura sustentável e uma agricultura ecológica, biológica, orgânica. Tomando em consideração que cerca de $70 \%$ dos alimentos são produzidos por pequenos agricultores, muitas vezes mulheres, é fundamental compreender o que eles/as fazem e porque é importante proteger a sua sabedoria. De fato, as sementes locais são mais resistentes porque mais adaptadas às condições locais e às pragas e contribuem para a biodiversidade (Mori e Onorati, 2016).

Em muitos casos, em áreas urbanas e aldeias rurais durante ou após uma guerra (como nos casos de Moçambique, Angola ou Timor Leste), uma inundação ou uma seca (como na África do Sul, Moçambique, Zâmbia ou Tanzânia), colheitas perdidas ou medíocres de forma recorrente devido às mudanças climáticas (por exemplo, Chade ou Níger) ou apenas como uma questão de sazonalidade, falei com pessoas que estavam famintas, que estavam reduzindo a quantidade de comida consumida em cada refeição ou reduzindo o número de refeições diárias para enfrentar a fome. Outros apenas passavam os seus dias e toda a sua vida procurando comida, com muito pouco descanso. Lembro-me muito vividamente de uma mulher em Moçambique que me disse "vocês, os brancos, vocês devem ser felizes". Perguntei o porquê. Ela disse "porque vocês têm comida. Vocês não discutem por causa da comida". Em outra ocasião, tentando identificar a concepção êmica da saúde no centro de Moçambique, observei quanto é importante a disponibilidade de alimentos para garantir a felicidade, a saúde e a forma como as pessoas estavam conectando essas duas noções.

O papel central dos alimentos nas comunidades pobres é assustador. Viver cada dia é uma conquista sobre a incerteza. Todos os dias é a mesma busca por comida. Ter alimentos durante todo o ano é um critério de riqueza em muitos países em desenvolvimento. As pessoas pobres lutam para comer a maioria dos dias de suas vidas. As pessoas não têm a possibilidade de escolher entre diferentes estilos de vida (Sen, 1983, 1987). As pessoas pobres, muitas vezes, não têm nenhuma escolha. Entretanto, a linguagem biomédica e de desenvolvimento relacionada à nutrição tende a ocultar a dimensão psicológica e emocional da fome e da privação. Nos locais onde a privação, o medo, a doença e a morte são as realidades cotidianas, é difícil se dignificar. Viver uma vida inteira sem dignidade e ser considerado um cidadão de segunda ordem é a realidade da maioria das mulheres do mundo e das pessoas vítimas de discriminação com base na sua raça/cor/etnia ou a sua classe social.

E a maioria dos dias de sua vida, muitas das pessoas pobres comem uma comida monótona. "We do not diversify food. We eat ugali every day and rice once a 


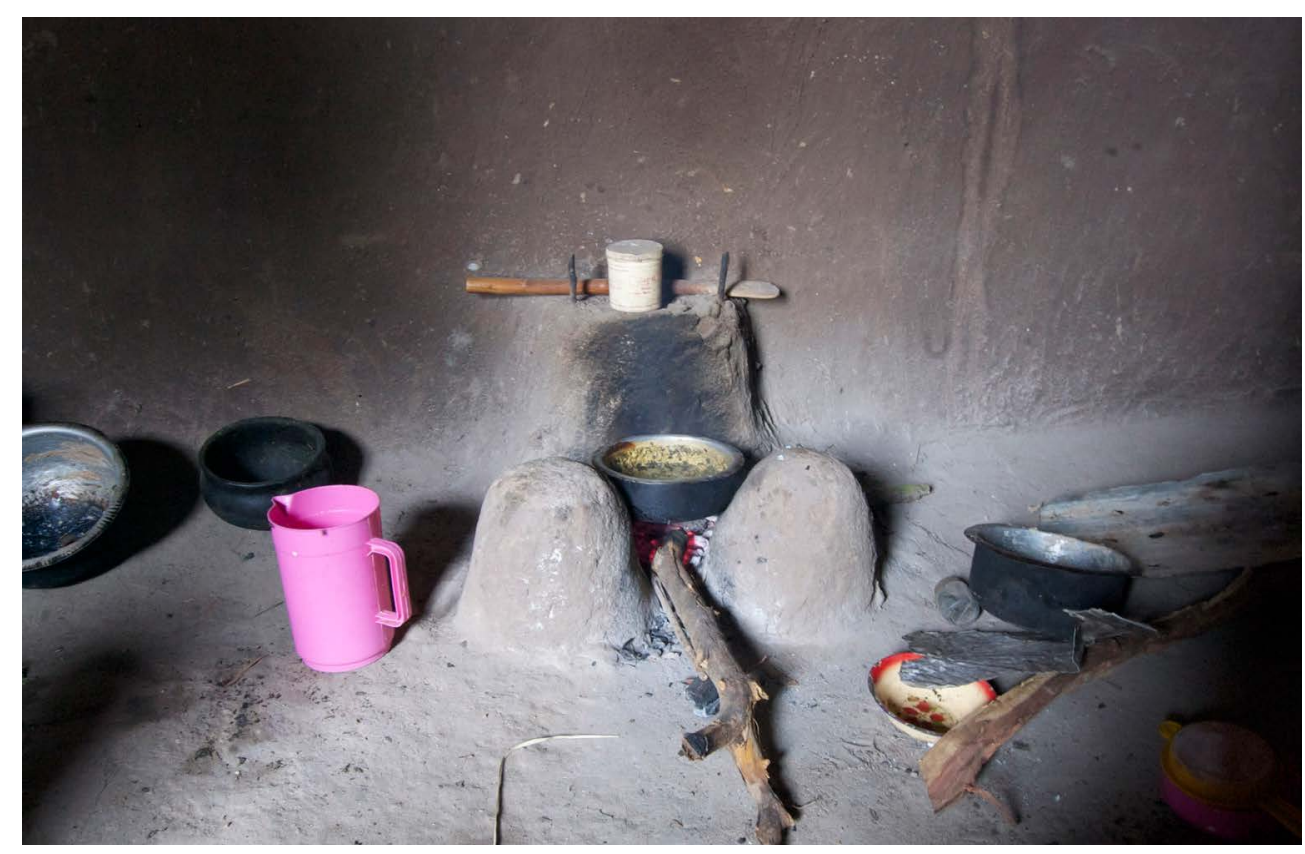

month"12 disse-me uma mulher no distrito de Majiri, na Tanzânia Central. Costariam de diversificar, melhorar sua dieta, mas são limitados pela falta de dinheiro, alimentos nutritivos acessíveis, informações, soluções técnicas para produzir alimentos de qualidade, erosão do solo e perda da biodiversidade, que impacta negativamente o acesso aos alimentos comestíveis não cultivados e sobre as qualidades nutricionais dos alimentos cultivados ${ }^{13}$. Muitas vezes, os alimentos não cultivados não são valorizados ou são até desprezados pelas elites nacionais e internacionais. Estes alimentos não constam nos manuais de nutrição.

É desconcertante observar o que não foi feito desde a publicação do relatório do Clube de Roma de 1972 para se chegar à situação atual: aumento da população, redução das áreas férteis, aumento dos gases de efeito estufa, desmatamento, redução da biodiversidade e extinção de espécies animais e vegetais com consequências sobre o clima e sobre o equilíbrio entre espécies, tais como a polinização das plantas ou o controle das espécies pelos seus predadores naturais (Ceballos, Ehrlich e Dirzo, 2017). É perturbador ver, entre agosto e setembro de 2017, a chuva e as inundações na Ásia matando mais de 1.400 pessoas, o furacão Harvey em Houston e três furacões no Atlântico Irma, José e Katia. O aumento das catástrofes naturais e da sua intensidade é preocupante. Pouco se fala e, sobretudo, pouco se faz para reverter esta violência que atinge essencialmente os mais pobres.

\section{OLHAR PARA A FRENTE: SAIR DA VIOLÊNCIA}

Violência de gênero, violência contra o outro, violência da pobreza e da fome, violência multifacetada, multicamada, acumulação de violência proveniente de

\section{Figura 4}

Uma cozinha no distrito de Sanza na Tanzânia, 2014. Foto de Brigitte Bagnol. a comida. Comemos ugali todos os dias e arroz uma vez por mês". Ugali é um mingau duro, feito de milho branco.

13 Ver Scientific American Journal, "Dirt Poor: Have Fruits and Vegetables Become Less Nutritious?". Disponível em: https://www.scientificamerican. com/article/soil-depletionand-nutrition-loss/. 
lados múltiplos. Proveniente de todos os lados. Um meio ambiente agressivo, um sistema econômico e de relacionamento com o Estado agressivo, relações entre indivíduos agressivas, engrenagens de violências diárias, microviolências e macroviolências se sobrepondo em milhares de composições possíveis, eis a imagem do mundo no qual vivo com bilhões de pessoas.

Apesar de ter muitas razões para desconfiar da possibilidade de uma forma de civilização alternativa que permita a cada indivíduo expressar completamente a sua individualidade, a sua diferença, as suas angústias e os seus sonhos, aparecem algumas possibilidade de esperança. Muitos autores estão envolvidos em projetos visando a mudança de mentalidade e de práticas (Ripple et al., no prelo; Alders et al., 2016, no prelo).

A noção de "capacidades" de Amartya Sen e Martha Nussbaum é interessante aqui, porque integra a dimensão subjetiva da qualidade de vida, alterando a concepção idealista e pouco prática da universalidade dos direitos humanos, integrando dados microeconômicos e sociais (Nussbaum e Sen, 1990; Sen, 1999). Nussbaum considera que "não ter o seu desenvolvimento emocional destruído pelo medo, por uma demasiada ansiedade, ou por eventos traumáticos de abuso ou negligência" (2003: 79) deve ser constitutivo de uma das suas 10 capacidades, que ela identifica e chama de "emoções". O desenvolvimento, do ponto de vista de sem, consiste em remover os constrangimentos que limitam as escolhas das pessoas e consequentemente não lhes permitem exercer a sua ação racional. 0 desenvolvimento é concebido como o aumento das liberdades, das opções entre as quais escolher. Sen opõe à noção de desenvolvimento medida pelo produto interno bruto, as rendas pessoais, etc. um desenvolvimento centrado no ser humano, com a melhoria da sua vida e a possibilidade de exercer escolhas liberdades.

De acordo com Boaventura de Sousa Santos "não pode existir uma justiça social sem uma justiça cognitiva" ('there is no global social justice without global cognitive justice") (2008:xlix). Porque a violência se exprime pela rejeição do conhecimento dos grupos oprimidos, para que haja justiça social há necessidade que o conhecimento dos grupos oprimidos seja reconhecido. Trata-se mesmo de um projeto de conhecimento (Sousa Santos, 2008; Latour, 2012), de análise do passado para melhor entender o presente. $O$ reconhecimento de formas de saber e de realidades fora daquelas dominantes são reivindicações fundamentais, expressas por muitos movimentos, que sejam pós-coloniais, relacionados como gênero, com as lutas dos camponeses ou dos ecologistas.

O projeto pós-colonial advoga e procura sair de uma relação de poder baseada na dominação do mundo "ocidental" (Europa, América do Norte, Austrália e Nova Zelândia) sobre o resto do mundo. O título do livro de Dipesh Chakrabarty (2000) "Provincializar a Europa" é um bom resumo do programa pós-colonial. Ngugi wa Thiong'o (Decolonising the Mind) advoga pela importância das línguas africanas 
e uma atitude crítica em relação às línguas herdadas do colonialismo. Achille Mbembe (2010), em Sortir de la grande nuit fala de "declosion du monde" para se referir "ao abrir a cerca, retirar uma cerca", uma noção que também diz respeito à eclosão, ao nascimento de algo de novo, a fazer ressurgir a humanidade, permitindo ao colonizado sair da cerca e falar por si mesmo. Desenvolver a capacidade de ser si mesmo. Sair da cerca da raça e da relação de colonizador/colonizado.

De acordo com Edgar Morin (2017) "chegou o momento de mudar de civilização" e de "re-encantar a esperança". "O único verdadeiro antídoto contra a tentação barbaria tem o nome do humanismo" advoga Morin perante a situação de crise planetária que atravessamos. Ele evidencia duas formas de barbaridade. Hoje, a primeira é a barbaridade do Daech, mas que ontem era também aquela do nazismo, do stalinismo, do maoísmo. O segundo tipo de barbaridade é a lei dos números, do cálculo (lucro, PIB, crescimento, desemprego, sondagem, etc.) (Morin, 2017).

Morin considera que o sistema educativo é inadequado, porque não ensina a viver. A tarefa da educação e da mudança de currículo universitário é fundamental, como o argumenta o movimento "decolonizing the university". O projeto de descoIonizar, despatriarcalizar, desmercantilizar, de eliminar as formas de violência de raça, classe, gênero e origem nas universidades implica transformar fundamentalmente o pessoal, as estruturas, as atitudes, o currículo, as formas de ensino.

É uma tarefa importante e necessária. Existe um nexo entre a problemática de gênero, a problemática de raça, as formas de pensar a ciência e o ser humano, as formas de produção industriais e agrícolas e a relação com a natureza. Se há uma necessidade de descolonizar a universidade, de descolonizar a sociedade e as mentalidades, no Sul, como no Norte, este processo deverá integrar um esforço para também despatriarcalisar a universidade e a sociedade. Não haverá justiça social se não há justiça para as mulheres. E neste processo de educação do respeito para com os seres humanos de todas as origens, independentemente do seu gênero, deverá se integrar a noção de respeito pelos seres não humanos e pelo planeta em geral. A compreensão de que somos interconectados enquanto seres humanos num planeta comum, é fundamental.

O objetivo é a criação de um outro relacionamento com a violência, estabelecendo um olhar crítico sobre o presente e o passado para produzir um futuro diferente: um mundo pós-violência. É necessário eliminar a violência para desenvolver uma nova civilização, uma civilização de bondade, respeito e justiça, ausente de humilhação e de crueldade, desenvolvendo uma maneira de estar em harmonia com o planeta.

Insisto muito sobre a necessidade de mudança no Norte também. Vive-se na França uma espécie de esquizofrenia, na qual, apesar de se saber que além do hexágono há territórios franceses - refiro-me aqui especificamente ao trabaIho de Françoise Verges (2001) -, pouco se sabe e se estuda nas escolas e nas 
universidades francesas sobre a violência que liga estes territórios à França e à sua história colonial e capitalista. Muitos dos problemas que se vivem agora na França, como a guetização da sociedade, a discriminação, o racismo contra os estrangeiros e os "franceses de origem imigrante", têm origem nesta cegueira. Nos discursos, parece que são os imigrantes que vieram para a França e esquece-se que foi a França, em muitos casos, que foi a estes países pilhar e matar.

Por meio destes olhares cruzados é possivel entender as interconecções das violências existentes em todos os cantos da sociedade onde nasci, com as violências nos vários recantos do mundo. Aquele que não se reconhece no sofrimento do outro, não percebeu que pertencemos todos à mesma história e que esta história ou estas histórias se comunicam, estão imbricadas umas nas outras de mil e umas formas.

Brigitte Bagnol viveu 30 anos na África Austral trabalhando com comunicação, nutrição e doenças infecciosas emergentes e aspectos de género. Ela colabora atualmente com a Universidade de Sydney numa pesquisa sobre Tanzânia e Zâmbia, observando o impacto de intervenções na agricultura e na criação de animais sobre o estatuto nutricional das crianças.

\section{REFERÊNCIAS BIBLIOGRÁFICAS}

ABUSHARAF, Rogaia Mustafa

2001 "Virtuous Cuts: Female Genital Circumcision in an African

Ontology", Differences: A Journal of Feminist Cultural Studies, 12 (1).

ALDERS, Robyn et al.

2016 "Approaches to Fixing Broken Food Systems". In:

ECGERSDORFER M, et al. (orgs.). Cood Nutrition: Perspectives

for the 21st Century. Basel, Karger, pp. 132-144.

No prelo "A Planetary Health Approach to Secure, Safe,

Sustainable Food Systems: A Clobal Discussion". Food Security.

ARENDT, Hannah

2010 Sobre a Violência. Rio de Janeiro, Civilização Brasileira. 
AWONDO, Patrick; GESCHIERE, Peter; REID, Graeme;

JAUNAIT, Alexandre; Le RENARD, Amélie e MARTEU, Élisabeth

2013 "Une afrique homophobe? Sur quelques trajectoires de politisation de l'homosexualité : Cameroun, Ouganda,Sénégal et Afrique du Sud".

Presses de Sciences Po (P.F.N.S.P.). Raisons politiques (1) n. 49:95-118

BAGNOL, Brigitte

2006 Cender, Self, Multiple Identities, Violence and Magical Interpretations in Lovolo Practices in Southern Mozambique. Cidade do

Cabo, tese de doutorado, University of Cape Town.

2008 "Lovolo e Espíritos no Sul de Moçambique". Análise Social, n. 187: 251-272.

2017 "The Aetiology of Disease in Central Mozambique with a Special Focus on HIV/AIDS". African Studies, vol. 76: 205-220. Disponível em: http://dx.doi.org/10.1080/00020184.2017.1322867.

BACNOL, Brigitte; MATEBENI, Zethu; SIMON, Anne; BLASER, Thomas; MANUEL, Sandra; e MOUTINHO, Laura

2010 "Transforming Youth Identities: Interactions across "Races/ Colours/ Ethnicities", Cender, Classes and Sexualities in Johannesburg, South Africa". Sexuality Research and Social Policy, n.7: 283-297.

BLASER, Thomas; BAGNOL, Brigitte; MATEBENI,

Zethu; SIMON, Anne e MANUEL, Sandra

2010 "Raça, Ressentimento e Racismo: Transformações na África do Sul". Cadernos Pagu, 35: 111-137.

BOURDIEU, Pierre

1989 O Poder Simbólico. Rio de Janeiro, Bertrand Brasil.

1991 Language and Symbolic Power. Cambridge, Polity Press.

BOURDIEU, Pierre et al.

1993 La Misère du monde. Paris, Edition du Seuil.

CASTELO Branco, Luis

2008 "África e a crise do Zimbabwe". Lusíada. Política Internacional e Segurança, n.1. 
CEBALLOS, Gerardo; EHRLICH, Paul R. e DIRZO, Rodolfo

2017 "Biological Annihilation Via the Ongoing Sixth Mass Extinction

Signaled by Vertebrate Population Losses And Declines". Proceedings

of the National Academy of Sciences of the United States of America,

vol. 114, n. 30, E6089-E6096, doi: 10.1073/pnas.1704949114.

CHAKRABARTY, Dipesh

2000 Provincializar a Europa. Postcolonial thought and historical difference. Princeton, Princeton University Press.

CHAMOISEAU, Patrick

2017 Frères migrants: Paris: Le Seuil.

CHIVAVA, Sérgio

2009 "Por que Moçambique é pobre? Uma análise do discurso de Armando Cuebuza sobre a pobreza". II conferencia do IESE, "Dinâmicas da pobreza e padrões de acumulação em Moçambique". Maputo, Instituto de Estudos Sociais e Económicos. Conference Papern. 19, Maputo, 22 a 23 de Abril de 2009.

CLACHERTY, Glynis

2015 "The Suitcase Project: Working with Unaccompanied Child Refugees in New Ways". In PALMARY et al. (orgs.), Healing and Change in the City of Cold, Peace Psychology Book Series, n.24, pp. 13-19.

CORRÊA, Sonia e PETCHESKY. Rosalind

1996 "Direitos sexuais e reprodutivos: uma perspectiva feminista". Physis, n.6 (1/2): 147-177.

CRIST, E.; MORA, C.; e ENGELMAN, R.

2017 "The Interaction of Human Population, Food Production, and Biodiversity Protection". Science, n.356: 260-264.

DAS, Veena

2007 Life and Words. Violence and the Descent into the Ordinary. Berkeley, University of California Press.

DUFUMIER, Marc

2007 "Agriculture comparée et développement agricole". Revue Tiers Monde, n. 191: 611-626. 
DUMONT, René

1973 L'Utopie ou la mort. Paris, Le Seuil.

EL SAADAWI, Nawal

1980 The Hidden Face of Eve: Women in the Arab

World. London: Zed Press, 1980.

EUROPEAN COORDINATION VIA CAMPESINA (ECVC)

2017 "Pushes for a United Front in Defense of Seeds", 13 de maio

de 2016. Disponível em: http://www.eurovia.org/ecvc-

pushes-for-a-united-front-in-defense-of-seeds/

FARMER, Paul

2004 "An Anthropology of Structural Violence". Current

Anthropology, v.45, n.3: 305-325.

FOOD AND ACRICULTURE ORGANIZATION (FAO)

2009 International Treaty on Plant Cenetic Resources for Food and Agriculture. Roma, FAO.

2015 The State of Food Insecurity in the World 2015. Strengthening the Enabling Environment for Food Security and Nutrition. Roma, FAO.

GEBRU, Hailu

2015 "A Review on the Comparative Advantages of Intercropping to Mono-Cropping". System Journal of Biology, Agriculture and Healthcare, vol.5, n.9. Disponivel em: http://www.iiste.org/ Journals/index.php/JBAH/article/viewFile/22307/23138.

GIDE, André

1926 Les Nourritures terrestres. Paris, Gallimard.

GIRARD, René

1972 La Violence et le sacré. Paris, Editions Bernard Crasset.

GUENDEL, Sabine

2005 "What is Agrobiodiversity?". In Building on Cender, Agrobiodiversity and Local Knowledge. Roma, FAO. 
HADLAND, Adrian (org.)

2008 Violence and Xenophobia in South Africa: Developing Consensus,

Moving to Action. Pretoria, Human Science Research Council.

HANLON, Joseph

1984 Mozambique, the Revolution Under Fire. Londres, Zed Books.

1997 Paz sem benefícios: como o FMI bloqueia a reconstrução de

Moçambique. Maputo, Centro de Estudos Africanos.

HÉRITIER, Françoise

1996 De La Violence. Paris, Edition Odile Jacob.

INS e INE

2015 Inquérito de indicadores de imunização, malária e HIV/SIDA em Moçambique (IMASIDA) 2015. Relatório de Indicadores Básicos de HIV. Maputo, INS e INE.

LATOUR, Bruno

2012 Enquête sur les modes d'existence. Une Anthropologie des modernes. Paris, La Découverte.

MACHEL, M. Samora

1974 A Libertação da Mulher é uma Necessidade da Revolução, Garantia da sua Continuidade, Condição do seu Triunfo. Caderno 4. Maputo, Partido FRELIMO, Estudos de Orientação.

MARLEY, Bob

1980 Redemption Song.

MARX, Karl

1973 Le Capital, livre premier tome III. Paris, Editions Sociales.

MATT, Liebman e DYCK, Elizabeth

1993 "Crop Rotation and Intercropping Strategies for Weed Management". Ecological Society of America.

MAZZEO, John; RODLACH, Alexander; e BRETON, Barrett P.

2011 "Introduction: Anthropologists Confront HIV/AIDS and Food Insecurity in Sub-Sahara Africa". Annals of Anthropological Practice, 35: 1-7. 
MBEMBE, Achille

2010 Sortir de la grande nuit. Essai sur l'Áfrique décolonisée.

Paris, Éditions la Découverte.

2016 Politiques de l'inimité. Paris, Éditions la Découverte.

MISACO, Jean Pierre; LANDAU, Loren B.; e MONSON, Tamlyn

2009 Towards Tolerance, Law and Dignity: Addressing Violence against

Foreign Nationals in South Africa. Johannesburg, Forced Migration

Studies Programme at the University of the Witwatersrand.

MORI, Stefano e ONORATI, Antonio

2016 Legal Framework for Farmers' Seeds System: Who Owns the Seeds?

Position paper for Centro Internazionale Crocevia, Roma.

MORIN, Edgar

2017 Le Temps est venu de changer de civilisation. Dialogue avec Denis Lafay, Paris, Eds De L'aube. http://www.agefi.com/ageficom/europe-et-monde/ detail/edition/online/article/pour-le-sociologue-et-philosophefrancais-de-94-ans-\%33C\%3Cle-seul-veritable-antidote-a-latentation-barbare-a-pour-nom-humanisme\%3$\% \% 3 \mathrm{E}$-grand-interview-sur-letat-du-monde-et-de-la-france-419267.html

NCUGI, wa Thiong'o

1986 Decolonising the Mind. The politics of language in African literature. Nairobi: East African Educational Publishers.

NNAEMEKA, Obioma

2005 "African Women, Colonial Discourses, ans Imperialist Interventions: Female Circumcicsion as Impetus". In: NNAEMEKA, Obioma (org.). Female Circumcision and the Politics of Knowledge. African Women in Imperialist Discourses. Londres, Praeger, pp 27-47. NUSSBAUM, Martha

2003 "Capabilities as Fundamental Entitlements: Sen and Social Justice". Feminist Economics, vol. 9, n. 2-3: 33-59.

NUSSBAUM, Martha e SEN, Amartya

1990 The Quality of Life. Oxford, Clarendon Press 
RIPPLE, William ]. et al.

No prelo 'World Scientists' Warning to Humanity:

A Second Notice". BioScience.

SARTRE, Jean-Paul

1952 Saint Cenet, comédien et martyr. Paris, Gallimard.

1978 O Existencialismoé um humanismo. Lisboa, Editorial Presença,

SEN, Amartya

1999 Development as Freedom. Oxford, Oxford University Press.

2006 Identity and Violence: The Illusion of Destiny. Nova Delhi, Penguin Books.

SONTAG, Susan

1993 Regarding the Pain of Others. Nova York, Picador.

SOUSA SANTOS, Boaventura. (org.)

2008 Another Knowledge is Possible. Beyond Northern

Epistemologies. Londres, Verso.

STEYN, Melissa

2001 "Whiteness in the Rainbow: Experiencing the Loss of Privilege in the New South Africa". In: HAMILTON, Charles V.; HUNTLEY, Lynn; ALEXANDER, Neville; GUIMARÃES, Antonio Sérgio Alfredo e JAMES, Wilmot. (orgs.) Beyond Racism: Race and Inequality in Brazil, South Africa and the United States. London, Lynne Rienner, pp.85-103.

TWAGIRAMUNGU, Fabie

2006 Environmental Profile of Rwanda. European Kigali, European Commission and Republic of Rwanda.

UN WOMEN

2015 Progress of the World's Women 2015-2016. Transforming

Economies, Realizing Rights. Nova York, UN Women.

UNITED NATIONS

2015 World Population Prospects, the 2015 Revision. New York, United Nations.

VERCES, Françoise

2001 Abolir l'esclavage, une utopie coloniale. Paris, Bibliothèque Albin Michel. 


\section{VIA CAMPESINA}

2011 Peasant Seeds: Dignity, Culture and Life. Farmers in Resistance to Defend their Right to Peasant Seeds. Bali Seed Declaration. Disponível em: https://viacampesina.org/en/index.php/main-issuesmainmenu-27/biodiversity-and-genetic-resources-mainmenu37/1030-peasant-seeds-dignity-culture-and-life-farmersin-resistance-to-defend-their-right-to-peasant-seeds.

WALTER, Benjamin

1921 Reflections. Essays, Aphorisms, Autobiographical Writings. Nova York, Schocken Books.

WEIL, Simone

1955 Réflexions sur les causes de la liberté et de l'oppression sociale. Paris, Éditions Gallimard.

ZHANG, F. e LI, L.

2003 "Using Competitive and Facilitative Interactions in Intercropping Systems Enhances Crop Productivity and Nutrient-Use Efficiency". Plant and Soil, n. 248: 305-312.

\section{WEBSITE}

Scientific American Journal. Diet Poor: Have Fruits and Vegetables Become Less Nutritious? Disponível em: https://www.scientificamerican. com/article/soil-depletion-and-nutrition-loss/

Centro Internazionale Crocevia. Press Release Copa Cogeca, 10 de maio de 2016. Disponível em: http://www.croceviaterra.it/ogm/copacopgecaun-comitato-delle-organizzazioni-agricole-maggioritarie-alservizio-di-un-pugno-di-imprese-semamentiere-e-non-solo/ 
Barbarities and violences

\section{ABSTRACT}

The author outlines her trajectory of intimate coexistence with the violence and the consequences inflicted on the mind and body of all the people who are involved in them. With examples from Mozambique, South Africa and Rwanda and violence linked to war, hunger, HIV / AIDS and gender, she articulates, through fragments of her experiences, the different layers and forms of violence that afflict the most unprotected. The approach of physical violence, structural violence, symbolic violence and its various combinations destroy human beings and, above all, those who have to live with the multiplicity of their forms. The proposal is to find ways to develop a new ethic of citizenship, empathy and solidarity that seeks to disarm these violences.

Recebido em 30 de maio de 2017. Aceito em 7 de novembro de 2017.

\section{KEYWORDS}

Violences, Planetary Health, Hunger, Poverty, Cender 